\title{
Ritual, rage and revenge in 2 Maccabees 6 and 7
}

\author{
Author: \\ Pierre J. Jordaan ${ }^{1}$ \\ Affiliation: \\ ${ }^{1}$ School of Ancient \\ Languages, North-West \\ University, Potchefstroom \\ Campus, South Africa \\ Correspondence to: \\ Pierre Jordaan \\ Email: \\ pierre.jordaan@nwu.ac.za \\ Postal address: \\ PO Box 19510, Noordbrug \\ 2522, South Africa \\ Dates: \\ Received: 31 May 2012 \\ Accepted: 24 Aug. 2012 \\ Published: 17 Oct. 2012 \\ How to cite this article: \\ Jordaan, P.J., 2012, \\ 'Ritual, rage and revenge \\ in 2 Maccabees 6 and 7', \\ HTS Teologiese Studies/ \\ Theological Studies 68(1), \\ Art. \#1271, 5 pages. \\ http://dx.doi.org/10.4102/ \\ hts.v68i1.1271
}

(C) 2012. The Authors.

Licensee: AOSIS

OpenJournals. This work

is licensed under the

Creative Commons

Attribution License.
The martyrs in 2 Maccabees 6 and 7 have been explored in various ways. In their commentaries on 2 Maccabees, Jan Willem van Henten and Daniel Schwartz proposed that the deaths of the martyrs should be seen as human sacrifices to please the deity. This idea has either been challenged or supported by scholars. This article supported the idea of human sacrifice, and applied the view of Richard DeMaris of the martyr's deaths as exit rite to the above-mentioned texts. In essence this amounts to ritual critique. The results were surprising, and proved the model of DeMaris as a useful tool to examine rituals. The conclusion was reached that 2 Maccabees 6 and 7 is indeed an exit rite.

\section{Introduction}

Ritual critique has seen a dynamic development over the past ten years in the study of both the Old Testament and New Testament. It has developed from humble beginnings as a study without much theoretical background into a field with extensive theory and scrutiny of rituals within texts. With regard to the Old Testament, the following studies, amongst others, are worth mentioning:

- David Wright's study Ritual in Narrative (2001)

- Ithamar Gruenwald's Rituals and Ritual Theory in Ancient Israel (2003)

- Roy Gane's examination of purification offerings in Leviticus (2005)

- Jonathan Klawans's Purity, Sacrifice and Temple (2005), which also shows the prolific development of theory in examining rituals in a broader academic environment.

Ritual studies of the New Testament include the following:

- Semeia 67 (1994:7-12), edited by Mark McVann, openly states that they were venturing into turbulent, murky and even uncharted waters.

- Christian Strecker's Die liminale Theologie des Paulus: Zugänge zur Paulinischen Theologie aus kulturanthropoligscher Perspecktive (1999).

- Dimensions of Baptism: Biblical and Theological Studies by Porter and Cross (2003).

These publications on rituals and the theory of rituals have contributed to the better understanding of rituals in a biblical context, as well as in general religious contexts. Vast progress has been made in understanding rituals as characteristic of religious communities.

\section{Problem}

In the area of the so-called deuterocanonical books or Apocrypha of the Old Testament, not much has been done on the scrutiny of rituals. Rituals are merely identified as circumcision, sacrifice, prayer, the keeping of the Sabbath and the commemoration of holy days. With the possible exception of Jan Willem van Henten (2004), in his book, The Maccabean Martyrs as Saviours of the Jewish People, A Study of 2 and 4 Maccabees, the identification and ritualistic significance of the martyrs in 2 Maccabees 6 and 7 until now also has not been attempted. Ritual significance here denotes (1) the identification of the ritual, (2) determining whether it is implicit or explicit and (3) detecting the underlying theme - atonement, cleansing, substitution or whatever it might be.

Until now different scholars have treated the martyrs in 2 Maccabees in different ways. Most commentaries merely record the martyr narratives in 2 Maccabees 6 and 7, without providing much more than a surface reading. Moffat (in Charles 1913:125-154), as well as Kamphausen (1921,) are both good examples of this approach in that they say quite a lot about the different text variations and codices of 2 Maccabees 6 and 7, but never ask questions such as 'what did these stories actually mean to a certain religious community' and 'why were the narratives recorded and presented in a specific way'? Thus little has been proffered with regard to these respective texts' deeper significances and meanings for the very communities that produced them. Jonathan Goldstein (1983:316) for example, deals in his commentary on 2 Maccabees extensively with the martyrs in Chapters 6 and 7, but does not investigate any ideas of atonement, cleansing or even 
catharsis implied by their stories. The underlying metaphor of sacrifice and its function goes unrecognised. The same is true of the various introductions to the Apocrypha given by many acknowledged scholars. Erich S. Gruen (1998, 2002:275), for example, touches on various motives such as propaganda and humour, but does not proffer a connection between the martyrs and the concept of sacrifice. Again, David A. deSilva only hints at the possibility that the martyrs' death might have some atoning effect, but does not suggest a scheme as to how this atonement works. George W.E. Nickelsburg (2005:108-110) raises an expectation with his statement that ' 2 Maccabees is a refreshing example of a text that muddies the waters and breaks the stereotypes', and elaborates on the idea of resurrection, but nevertheless says nothing about the sacrificial nature of the martyrs in 2 Maccabees 6 and 7. Indeed, as was intimated earlier, Jan Willem van Henten (1997) was the first and only scholar to bring the idea of the martyrs' atoning death in 2 Maccabees to the fore. One of his main arguments for his point of view is based on the use of the

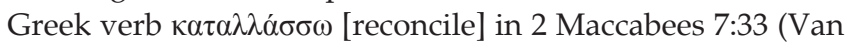
Henten 2004:156, 160). He argues that the idea of atonement by death is not completely foreign to second temple Judaism, and uses texts such as the last song of the suffering servant in Deutero-Isaiah (Is 52:13-53:12) as proof for his view. After Van Henten, Daniel R. Schwartz (2008), in his commentary on 2 Maccabees, follows Van Henten's approach of ten years earlier. Both of these scholars argue quite convincingly from various texts in the Old Testament that the idea of sacrificial atonement was not unusual to Judaism and that it also had a firm grounding in Greek culture. Schwartz (2008:299) states in this regard that 'the present chapter emphasizes repeatedly that the death of martyrs causes God to become reconciled with his servants'. The problem is that neither Van Henten nor Schwartz engaged with the already well-developed area of ritual critique. Ritual critique would be appropriate to investigate the martyr texts of 2 Maccabees 6 and 7, because all relevant elements of a ritual are present, namely sacrifice, atonement and catharsis.

An important question is the question on models: What model of ritual critique would be suitable to investigate the martyr texts of 2 Maccabees 6 and 7? Can the ritual be interpreted as a rite of passage (the announcement of a new dispensation) or might it be viewed as an exit rite (the ending of a dispensation)? The latter refers to a rite described in the gospel of Mark (DeMaris 2008:109) on the suffering and dying of Jesus of Nazareth. Many ritual similarities between the martyrs in 2 Maccabees 6 and 7 and the curative exit rite of Jesus of Nazareth can be indicated. Both stem from the ritual world of the ancient Mediterranean, both are carried out to rescue communities from threatening situations, and both sacrifices are presented to a deity with the desire to rectify a situation that has gone wrong in the devotion to the deity. Again, in both examples there is an individual or a group paying the ultimate price with their life for a community. Furthermore, in both narratives there are rumours of a subsequent reward for sacrificing an earthly life. The list of similarities could be extended further; therefore the method presented by DeMaris (2008:91-11) could constitute a worthwhile model for examining the martyrs's narratives of 2 Maccabees 6 and 7.
Some European scholars have engaged in a discussion on the issue of Jesus' beneficiary death. However, Van Henten (n.d.:32), in an unpublished article entitled 'Jewish Martyrdom and Jesus', still maintains his position that the martyrs served a sacrificial purpose and that there is a close link between Jewish martyrdom traditions and Jesus' beneficiary death. It would therefore be a worthwhile experiment to apply a model of ritual critique to the death of the martyrs in 2 Maccabees 6 and 7 in order to establish if there might be any links.

\section{Method}

DeMaris's (2008:98-109) model for examining curative exit rituals can be summarised as follows:

1. A group usually has to deal with a crisis.

2. There is an internal as well as external perception of the crisis, internal threats are sin and contamination, while the external threat is an enemy attack.

3. As soon as the contamination or pollution is localised and the supernatural power is beseeched, there is a ritual response by investing and divesting as a designated individual from the group undergoes a transformation of status and exits the group (by exceptional circumstances).

4. Consequently by this investing or divesting there is a 'driving out' as well as a 'driving towards' action.

5. The result is different effects by different vehicles or agencies both on the internal and external levels.

On the internal level the effects can be purification, purging, catharsis and elimination, while the vehicles or agencies for this are expulsion, transference, displacement and disposal. This process leads to pharmakos, which acts almost like a medication when it heals the internal pressure. On the external level the agencies or agents are emissary, substitute, vicarious and surrogate, while the effects are apotropaic, deflection, diversion and appeasement; this in turn leads to devotio as the deity is now served in the correct manner.

This process can be depicted schematically (see Figure 1 on the next page).

\section{Application of method The group crisis}

The crisis that faced the Jews, according to 2 Maccabees, was immense. All levels of their religious and public life were threatened. The text is quite elaborate about the various ominous occurrences.

The many ways in which the sanctuary in Jerusalem was defiled can be summarised as follows:

- There was an attempt to steal the temple offerings intended for the poor. 2 Maccabees 3:13-14 states:

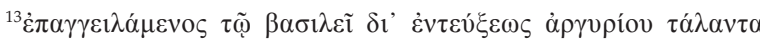

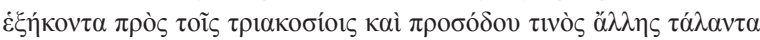

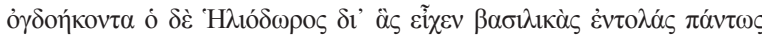

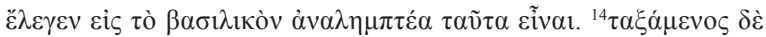

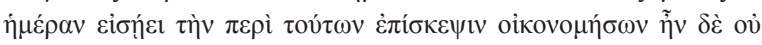

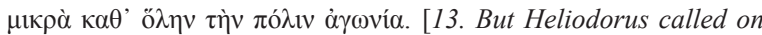
the decree of the king and said that all of it had to be transferred to the royal treasure. 14. He also set a day on which he himself will
} 
enter to inspect things and wouldmake arrangements. Concerning this there was no small agony in the whole city.]

- In 2 Maccabees 4:8 it is stated that a priest 'Jason' was appointed by Antiochus Epiphanus through payment:

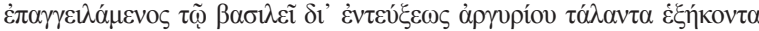

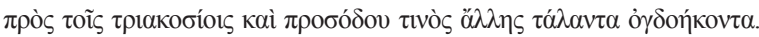
[He approached the king with a promise of threehundred and sixty talents of silver and eighty talents from another source of revenue.]

- This priest did not think the ways of the forefathers and temple duty was important, and therefore he imported Hellenising ways. 2 Maccabees 4:13-14 states:

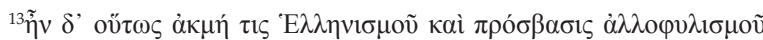

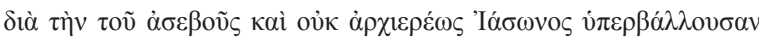

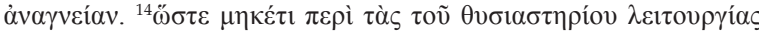

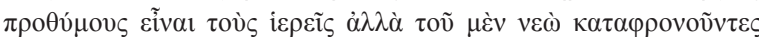

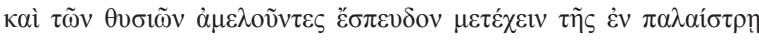

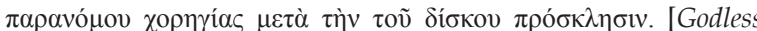
wretch that he was and no true high priest, Jason set no bound to his impiety, indeed the Hellenising reached such a pitch that the priests ceased to show any interest in serving the altar, but scorning the temple and neglecting the sacrifices, they would hurry at the stroke of the gong to take part in unlawful wrestling.]

- Antiochus Epiphanes himself entered the most holy of the temple and helped himself to sacred objects as can be seen in 2 Maccabees 5:15-16:

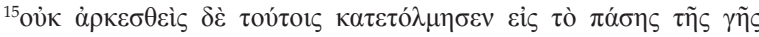

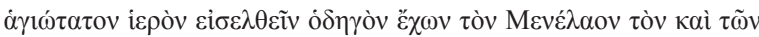

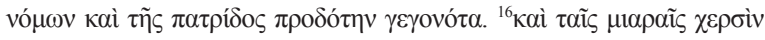

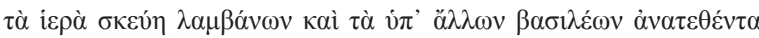

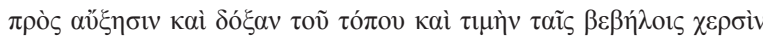

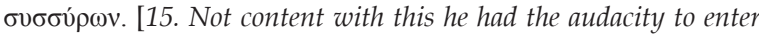

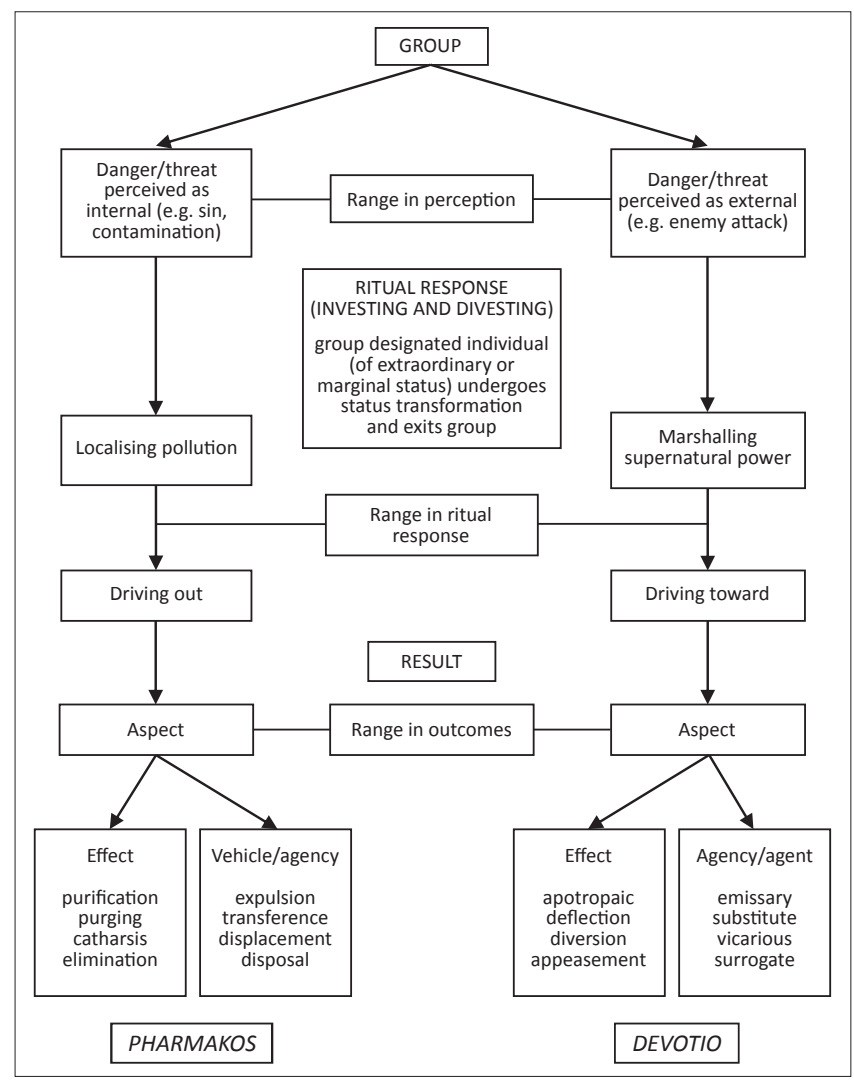

Source: DeMaris, R.E., 2008, The New Testament in its Ritual World, Routledge, London/ New York.

FIGURE 1: DeMaris's schematic presentation. the holiest temple on earth with Menelaos, that traitor to the laws and to his country, as his guide, 16. and with impure hands he seized the sacred vessels and with impious hands he seized the offerings presented by other kings for the aggrandizement, glory and dignity of the holy place.]

- In Chapter 6, in respectively 2 Maccabees 6:2a and 2 Maccabees 6:4-6, the worst atrocities against the temple in Jerusalem are mentioned:

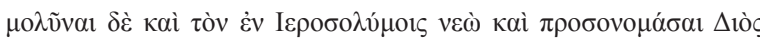
'O $\lambda v \mu \pi$ íov ... [And the temple in Jerusalem was defiled and dedicated to the Olympian Zeus.]

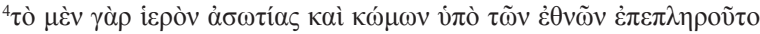

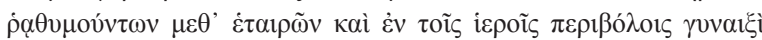

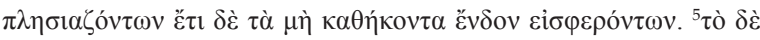

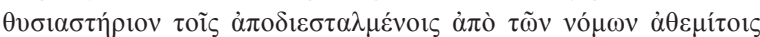
$\dot{\varepsilon} \pi \varepsilon \pi \lambda \eta \dot{\rho} \omega \tau$ [ [4. The temple was filled with decadence by gentiles, who took their pleasure with prostitutes and had sexual intercourse with women in the sacred precincts introducing other indecencies within. 5. The altar of sacrifice was loaded with victims proscribed by the law as profane.]

- With regards to the public religious life we read the following in 2 Macc2 Maccabees 6:6:

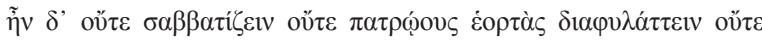

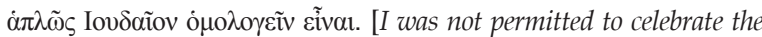
Sabbath or forefatherly feasts or to openly confess that I am a Jew.]

- Jews had to celebrate the birthday of the king and festivals of foreign deities. In 2 Maccabees 6:7 we read:

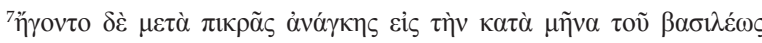

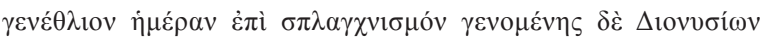

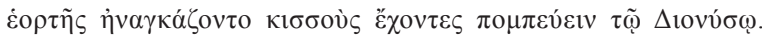
[7. People were driven by harsh compulsion to take part in the monthly ritual meal commemorating the king's birthday; and when a feast of Dionysus occurred, they were forced to wear ioy wreaths and walk in the Dionysian procession.]

- Jews were killed if they did not participate in Hellenising practices and their women publicly murdered for having their babies circumcised. In 2 Maccabees 6:8-10 we read the following:

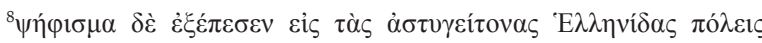

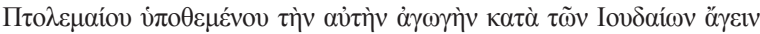

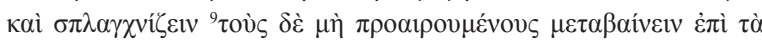

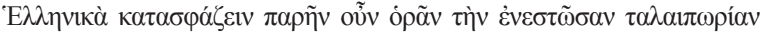

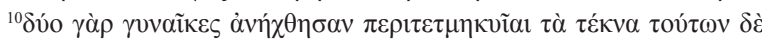

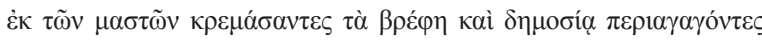

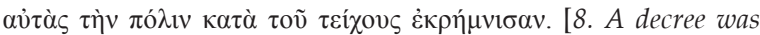
issued at the instance of Ptolomeus for the neighbouring Greek cities, enforcing the same conduct on the Jews there, obliging them to share in the sacrificial meals. 9. And ordering execution of those who would not voluntarily conform to Greek customs 10. Because two women were charged with having circumcised their children. They were paraded publicly around town, with their babies hung on their breasts and then thrown over the city walls.]

- Maybe the worst part of the crisis is found in 2 Maccabees 6:18-31 where Eleazar as well as in 2 Maccabees 7:1-42, where the mother and her seven sons, were publically forced to partake in the eating of swine. The eating of swine is an act that was forbidden by the Law of Moses. By challenging people in public to participate in such an act would be either to denounce or affirm the faith in the law of the forefathers. They actually had no choice: eat swine or die, conform or perish. 
It was said in $\S 2$, the fate of the martyrs in 2 Maccabees 6 and 7 might resemble a curative exit rite. All the elements of a curative exit rite are present, namely (1) a threat to the community, in this case both an internal and external one, (2) the designation of community members in response, who undergo status transformation over the course of the rite, (3) ritual action that concentrates and directs divine power, (4) entails the exit of the designated individual from the community toward the enemy and (5) the designated individual's vicarious action that diverts disaster away from the community and towards the enemy. These elements and their operation will now be discussed.

\section{The internal and the external perception of this crisis}

The internal perception of the crisis fits well into the framework set up by DeMaris (2008:98). As stated above, both the temple (religious life) and public life have been contaminated. In 2 Maccabees there is temple corruption, temple robbery and temple prostitution. All of this adds up to temple defilement, as the temple and its service have been contaminated. This constituted sin before the God of the Jews.

Together with this internal perception of sin and defilement there was also a real external dangers or threats. These included, amongst others, (1) the attacks of the enemy on the inhabitants of Jerusalem on the Sabbath, which meant that they could not fight back, (2) the throwing of women and their circumcised babies from the walls and (3) the forcing of Eleazar as well as the mother and her seven sons to eat swine in public and thereby violate their religious convictions.

In summary, on both the internal and external levels the Jews faced threats which would require extreme measures to address. These measures are described below.

\section{Ritual response by investing and divesting as a designated individual from the group undergoes status transformation and exits the group}

In this respect DeMaris (2008) states:

Curative exit rites overlap to some degree with purification rites, and their ends are much the same: the restoration or preservation of community wholeness and holiness. Differences remain however. Purification rites could and often used inanimate instruments like fire and water to achieve or restore purity, while curative exit rites always employed an animate - animal or human - instrument. Traditional communities can drive out impurity without parting with a community member, such as exorcism as part of new year's rites, but curative exit rites always employed an animate - animal or human - instrument. (p. 99)

It seems that in 2 Maccabees 6 and 7 a curative exit rite involving human sacrifice occurs. The lives of Eleazar, the mother and her seven sons are surrendered for the sake of the nation. There is a preponderance of cultic vocabulary that points in the direction of sacrifice. According to Leviticus $4: 28$, a sacrifice as atonement has to be perfect. In this

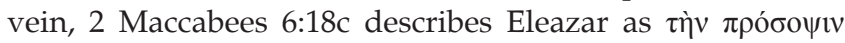

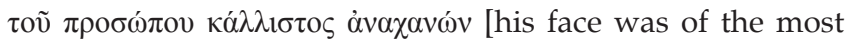
beautiful appearance].
Note the usage of the superlative here. Furthermore, Eleazar was incorruptible, and when he was given the chance to vंтокрı $\theta \tilde{\eta} v \alpha 1$ [to pretend]; (2 Macc 6:21) as though he ate swine, he refused. Eleazar's decision to rather die is described as a

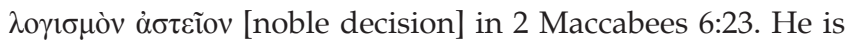

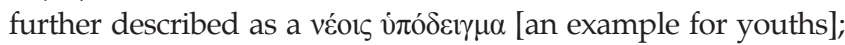
(2 Macc 6:28). All these descriptions point in the direction of a perfect sacrifice.

The same can be said about the mother and her seven sons. They are without reservation willing to die for the cause of not forsaking the ancestral law. The spokesman for all of

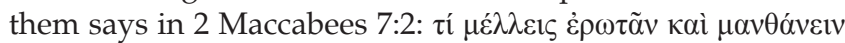

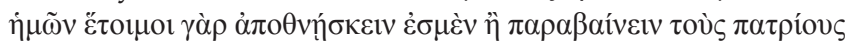
vónous [what do you want to ask and learn from us, because we are rather willing to die than to break to laws of our ancestors].

Whenever the sacrifice was perfect, true reconciliation ( $\alpha \tau \alpha \lambda \lambda \dot{\alpha} \sigma \sigma \omega$; [I reconcile] as described in 2 Maccabees 7:33 between God and his servants could take place.

According to the framework developed by DeMaris (2008:98), this is the investing stage of the ritual. It means that through the ritual there is an investing of a human or a group of humans on behalf of a larger group or religious community. Eleazar and the seven brothers and their mother were the designated people to make a stand on behalf of their fellow Jewish countrymen. The status transformation that they undergo is dying, thereby losing their earthly bodies and performing the highest possible sacrifice as humans. At the same time they also exit the group. They cannot die and still be part of the group; therefore they enter into a new way of existing. However, as always, this cannot be the last word about the martyrs, which introduces the next phase.

\section{Different effects by different vehicles or agencies on both the internal and external levels}

The final stage of the ritual sacrifice is now reached. The question that should now be asked in terms of DeMaris' (2008:98) framework is 'What effect did the sacrificial death of the martyrs have upon the community?' The answer to this question can be found in the text. On both the external and internal levels there were significant outcomes. As could be expected, almost immediately after the martyrdom described in Chapters 6 and 7 recovery sets in. In 2 Maccabees 8:1-2 one reads that Judas Maccabeus not only mobilises an army, but petitions God in 2 Maccabees 8:3 'to hear the blood of the

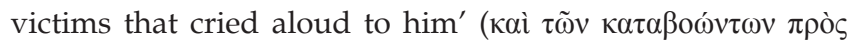

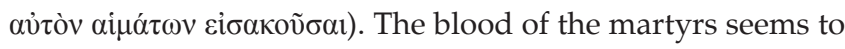
be the trigger that caused God to have mercy on them. Judas assembled an army and, although largely outnumbered, is instantly successful. This army kept before their eyes 'the unlawfulness that was committed by them against the holy

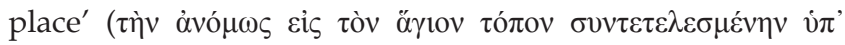

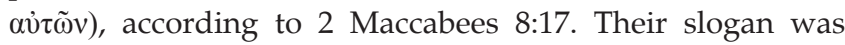

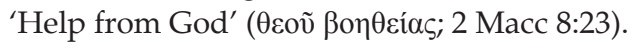

Thus what we have here is a radical turn-around in their fate, from losing to winning, from being on the run to attacking. In the language of ritual, the perfect sacrifice of the martyrs 
acted as a substitute for reconciliation. Accordingly, God was once again appeased and granted his nation their wish. In addition, after the martyrdom ordeal the Jews experienced a new devotion for God.

The same can to be said about the internal level. In 2 Maccabees 10, one reads that the temple was purified by Judas Maccabeus. All the foreign altars were pulled down. It is also argued here that these events took place after the martyrdom of 2 Maccabees 6 and 7. Again, it were the martyrs who caused the transference to take place. In this way the martyrs acted as a pharmakos, almost an antidote, to expel the foreign filth from within their midst.

\section{Conclusion}

Ritual critique, especially the curative exit rite as proposed by Richard DeMaris, has proved to be a worthwhile way to review the significance of the martyrs of 2 Maccabees 6 and 7. This approach highlighted and incorporated certain previously neglected areas in biblical rituals. Special emphasis was placed on the effect of a ritual on both the internal and external levels. No other commentary seems to have looked at the martyrs in 2 Maccabees 6 and 7 in this way. Ritual response to a crisis within a religious community and its operation on an internal and external level need further exploration.

\section{Acknowledgements Competing interests}

The author declares that he has no financial or personal relationship(s) which may have inappropriately influenced him in writing this article.

\section{References}

Charles, R.H., 1913, Apocrypha and Pseudepigrapha of the Old Testament, vol. 1, Oxford University Press, London.

DeMaris, R.E., 2008, The New Testament in its Ritual World, Routledge, London/New York.

DeSilva, D.A., 2002, Introducing the Apocrypha Message Context and Significance, Michigan Baker Academic, Grand Rapids.

Gane, R.E., 2005, Cult and Character: Purification Offerings, Day of Atonement and Theodicy, Eisenbrauns, Winona Lake.

Goldstein, J.A., 1983, 2 Maccabees, Doubleday, Garden City.

Gruen, E.S., 1998, Heritage and Hellenism: The Reinvention of Jewish Tradition, University of California Press, Berkeley/Los Angeles/London.

Gruen, E.S., 2002, Jews amidst Greeks and Romans, Harvard University Press, Cambridge/London.

Gruenwald, I., 2003, Ritual and Ritual Theory in Ancient Israel, Brill, Leiden.

Kamphausen, U., 1921, 'Das Zweite Buch der Makkabeer', in E. Kautzsch (Hrsg.), Apokryphen und Pseudepigraphen des Alten Testaments, pp. 81-118, JCB Mohr, Tübingen.

Klawans, J., 2005, Purity, Sacrifice and Temple: Symbolism and Supersessionism in the Study of Ancient Judaism, Oxford University Press, Oxford.

McVann, M., 2008, 'Introduction', Semeia 67, 7-12.

Moffat, J., 1913, '2 Maccabees', in R.H. Charles (ed.), Apocrypha and Pseudepigrapha of the Old Testament, pp. 125-154, Clarendon Press, Oxford.

Nickelsburg, G.W.E., 2005, Jewish Literature between the Bible and the Mishnah, Fortress Press, Minneapolis.

Porter, S.E. \& Cross, A.R. (eds.), 2003, 'Dimensions of Baptism', Biblical and Theological Studies Journal for the Study of the New Testament, suppl. 234.

Strecker, C., 1999, Die liminale Theologie des Paulus: Zugänge zur Paulinischen Theologie aus kulturanthropoligscher Perspecktive, doctoral dissertation, University of Göttingen, Göttingen.

Schwartz, D.R., 2008, 2 Maccabees. Commentaries on Early Jewish Literature, Walter de Gruyter, Berlin/New York. http://dx.doi.org/10.1515/9783110211207

Van Henten, J.W., 2004, The Maccabean Martyrs as Saviours of the Jewish People: A Study of 2 \& 4 Maccabees, Brill, Leiden/New York/Köln.

Van Henten, J.W., 1997, The Maccabean Martyrs as Saviours of the Jewish People: A Study of 2 \& 4 Maccabees, Brill, Leiden.

Van Henten, J.W., n.d., 'Jewish Martyrdom and Jesus' Death', unpublished article

Wright, D., 2001, Ritual in Narrative: The Dynamics of Feasting, Mourning and Retaliation Rites in the Ugaritic Tale of Aghat, Eisenbrauns, Winona Lake. 